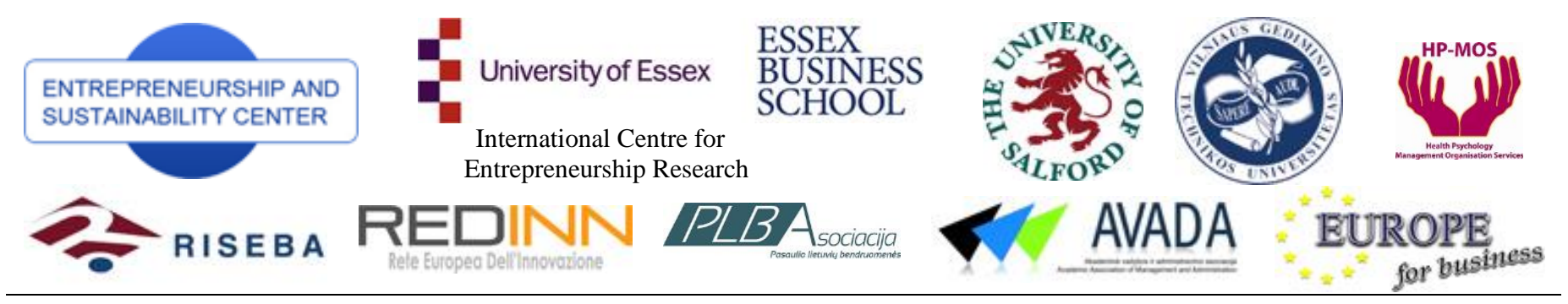

ENTREPRENEURSHIP AND SUSTAINABILITY ISSUES

ISSN 2345-0282 (online) http://jssidoi.org/jesi/aims-and-scope-of-research/

\title{
IF OBTAINED PROFESSIONAL COMPETENCES FOSTER SUSTAINABLE ENTREPRENEURSHIP: CASE OF VILNIUS UNIVERSITY OF APPLIED SCIENCES
}

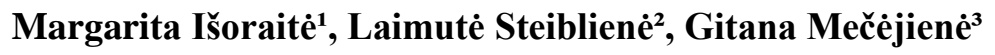 \\ ${ }^{1,2,3}$ Vilnius University of Applied Sciences, Didlaukio str. 49, Vilnius, Lithuania \\ E-mails:'misoraite@gmail.com; ${ }^{2}$. steibliene@gmail.com; ${ }^{3}$ bankininkyste@ekf.viko.lt
}

Received 6 February 2014; accepted 17 May 2014

\begin{abstract}
Article analyses theoretical definition aspects of competencies and professional competencies. Paper presents various definitions of competencies provided by different authors. Moreover this paper provides summarized understanding of professional competencies. This article analyses how employers who hire Vilnius College graduates perceive their professional qualities and competencies obtained during studies. Respondents of this research identified that they make hiring decisions based on individual interviews, recommendations and selection testing results. They are satisfied with all graduates, who eagerly improve their professional skills in various areas of expertise. Graduates have adequate theoretical knowledge base, decent organizational skills and have enough knowledge of foreign languages. General qualities of graduates were highly evaluated. This paper has showed that personal qualities have an impact on professional activities; these qualities are responsibility, activity in workplace and efficiency. Bank employers are willing to cooperate with Vilnius College faculty of economics administration. Primary areas of cooperation would be: "discussing content of internships" and "setting aims of internships".
\end{abstract}

Keywords: competencies, professional competencies, general competencies, special competencies, abilities

Reference to this paper should be made as follows: Išoratè, M.; Steiblienè, L.; Mečèjienè, G. 2014. If obtained professional competences are suitable for sustainable entrepreneurship: case of Vilnius University of Applied Sciences, Entrepreneurship and Sustainability Issues 1(4): 239-246.

DOI: http://dx.doi.org/10.9770/jesi.2014.1.4(6)

JEL Classifications: M12

\section{Introduction}

Competence of the employees affect performance of organizations, and is precondition of sustainable entrepreneurship (Laužikas, Mokšeckienė 2013; Raišienė, Jonušauskas 2013; Balkienė 2013; Raišienè 2012; Matei, Savulescu 2012; Raišienė 2013; Vasiliūnaite 2014). According to the Adamonienè and Ruibyte் (2010) one of the main problems in the organization is that the training system is not geared to the future. The prevailing traditional training system is inefficient. Therefore, staff capacity building has to be one of the priority directions of the development of integrated training systems based on competence development oriented to the future, enabling a quick response to the changing environment. 
The research problem. Competence problems has become acute. Meeting the operational needs of the system of rational development of education researchers in various fields have changed attitudes in professional competencies. As stated by David Long (2009) competence is the knowledge and the skills mix and the ability to adapt them to the specific circumstances, the performance of the functions, taking into account environmental constraints of the situation. The concept of competence is often used as a measure of knowledge and skills in order to describe the ability of employees to perform tasks very well, or the organization's ability to provide the highest quality service. It is important to determine what the employee organization must be: what a person is and what a person performs, it is considered to be expertise in. People can be seen as competent, when they pay enough attention to their performance, which is an important and valid organization. Can a person perform to the importance of the activities which are called input fields? A person is considered under the expertise in what he plays and how well and in what ways it does this. Changes in Lithuania person is becoming higher standards, so professional person of competence becomes one of the keys to the success. Today Lithuanian education policy needs a new content that is focused on narrow professional skills, but also in basic skills (in particular, the ability to learn independently to knowledge), values education, and present the person granting the necessary competencies. Is a policy which is closely linked to the educational content of different areas of real life, real problems and their solutions.

The object of investigation - Vilnius University of Applied Science graduates' professional competencies.

The aim - to assess professional competencies of Vilnius University of Applied Science graduates.

Objectives of the study:

- To analyze the theoretical aspects of professional competence;

- Assess employer's opinion of Vilnius College graduates of professional competencies.

\section{Professional competencies theoretical aspects}

The competence approach to human resources management has a long history. The early Romans already practiced a type of competence profiling in attempting to detail the attributes of a "good Roman soldier" (Draganidis and Mentzas 2006). The concept of competence was $\mathrm{u}$ sed by early $20 \mathrm{t} \mathrm{h}$ cent ury scient ific man agement (Taylor 1911) and later revised and redefined by McClelland, former Hay Group director, in the early seventies. According to McClelland (1973), competence concerns the relation between humans and work tasks; rather than knowledge and skills themselves, competence involves the knowledge and skills required to perform a specific job or task in an efficient way. Competences, from the Latin verb "competere" can be defined as an individual's core skills (motives, traits, self-concept, knowledge, and abilities) that are causally related to a specific, effective criterion and/or a superior performance at work (Spencer, L.M. and Spencer, S.M. 1993)

Competence concept first coined specialists in linguistics Noam Chomsky (1957), which introduced this concept in order to describe the subjective complex (multi-modal) and the use of language grammatical variance assumptions. In the seventh and eighth decades this concept identify social activities. In the eighth and ninth decades this concept moved into training discipline, which already contains concrete proposals for individual components of competence to develop and promote. As state Esteves (2009) the terms "a competence" or "competences" refer to a number of traits that can be pinpointed through action and observed and described without necessarily being attributed any value. In examples such as "questions the students", "diversifies mate rial", "uses technological resources", we are dealing with traits for which we can merely vouch presence and respective frequency or absence without qualifying them. The sum of such competences, taken in an analytical sense, is not enough to lead to a conclusion as to the overall competence of a professional. Le Boterf (1997) identifies six competences inherent to the professionals who know how to handle complexity:

- To be able to act relevantly;

- To be able to mobilise in a given context;

- To be able to combine;

- To be able to transpose;

- To be able to learn and to learn by learning;

- To be able to dedicate oneself. 
As stated by Jakubė, Juozaitis (2012) competence shall relate to personal conduct by the expertise to carry out certain activities in a professional environment, participate in a professional community discussions and represent their activity. As a component of excellence are identified knowledge, skills, attitudes, values and patterns of behavior, cultural and civic awareness. Competencies are divided into general and special. Special competence in higher education related to the discipline of study, reflecting the specifics of the program of study form the basis for the profession. General jurisdiction known as the transferable skills - is a general academic aptitude, which disseminated across all disciplines plane. For lifelong learning identified eight key skills, two of which - in foreign language and civic skills consist of full-fledged possibilities for a person to work productively in the international arena. According Liučvaitienè, Paunksnienè (2011) changing and increasing needs of modern society encourages continuous learning and the acquisition of new skills. The question is, what kind of things, and the extent of the professional competence? Competency - based learning system development becomes one of the very general purpose Lithuanian education system. Professional competence is a term used for a long time already, but so far there is no single definition. Law on Higher Education (2000) state that professional competence - professional acquired after the completion of their studies, or special professional integrated studies. Lithuanian Labour Market Training Authority (2007) state that competence is the ability to perform a specific job (task) in a real or simulated business situations. Jakiūnienè, Rekašiūtè (2010) state competence is understood as an individual's ability and knowledge, abilities, skills, attitudes, values and personal qualities to carry out certain activities, with emphasis on application of knowledge and skills, rather than their possession.

According Weinert (2001) competence is knowledge, experience and common sense of power. Qualifications and Training Foundation (2012) state that competence is the ability to perform certain tasks, based on acquired knowledge, abilities, skills and values. Competence can be viewed as a whole, and otherwise - is talking about competencies separate components. Competence emphasizes the holistic concept of human characteristics and values, attitudes to themselves as professionals who enable people to act in uncertain operational situations. A competent worker is able to perform the specific activity of the standard relevant to a particular organization and individual work, that competence includes the situation and personality dimensions. The professional competence of a particular concept in the work process does not necessarily mean only the realization of acquired skills, and is treated as an employee or a team's ability to achieve the organization's goals the performance requirements of the world. Competence is percaseived as a hierarchical structural formation as different hierarchical levels of performance required for the performance and different levels of expertise:

- Working with operational performance (the first level) is required masterfully learned behavioral level (elementary) competence, composed of components of clearly distinguishable;

- Improving the work (the second level of activity) necessary for the added expertise, which is based not only skillfully learned behavior, but also some knowledge.

- The work of internal and external variation (third level of activity) necessary integrated expertise and knowledge of the behavior based on the integration of activities that result in a substantial change;

- New job creation and skills transfer to the new business situation (the fourth level of activity) necessary for a holistic approach to the development of the overall competence.

According to Martišauskiene (2009) skills - is the outer expression of the essential human powers consist both the potential and nature of talent and knowledge, experiences and dispositions formed to implement them. Ability to become a key competence component at the purpose of granting to monitor, measure, tend to codify the basis of their excellence, even equated with excellence, when it is defined as "the ability to perform a certain task in a real or simulated situation". Necessary for the twenty-first century skills are:

- To act in a meaningful way and on their own (have a vision, set goals, apply strategies for rational management of resources.

- Take the initiative and responsibility for their actions.

- Continually learn and improve acquired skills.

- Think critically and solve problems.

- Communication and cooperation based on mutual understanding, the spirit of the consultation and consensus.

- To lead, to exchange ideas and to implement them creatively.

- Basic literacy (linguistic, mathematical, cultural). 
- Communication and information skills.

Competence can be defined as certain knowledge, skills, attitudes, and proven ability to perform tasks and actions in accordance with agreed requirements. Competencies can be identified with a particular knowledge of deep absorption, high quality student learning outcomes. The concept of identifying core competencies is not new to extension (Moore and Rudd 2004). A competence assessment is designed to evaluate individual knowledge, education, skills, experience, and proficiency to perform those assigned responsibilities (Herringer 2002). In contrast, performance evaluations are designed to evaluate how well an individual act ually performs their responsibilities. An extension agent who has to assume a variety of roles amongst the farmers must fulfill a number of different roles and therefore must prove her/his competence in many diverse areas. Based on Herringer's (2002) description of a competence assessment, competence can be defined as the ability of an individual to perform a task using his/her knowledge, education, skills and experience. Competencies, especially when used in competence assessments, should relate to the specific tasks required to perform successfully in a given position (Moore and Rudd 2004). The identification of key competencies provides for individual and organizational growth, and helps the organization meet future demands (Pickett 1998).

\section{Research data analysis}

It is necessary to develop a new generation of bankers who are able to work in a changing market conditions, solve complex problems and make rational management decisions. In response to the new world of work requirements and transferring them to banking degree program, it is necessary to improve the quality of higher education with a focus on program renewal.

The goal - to find out stakeholders' views on the Vilnius College graduates for practical activities.

The research method - a survey, literature analysis.

Timing - January 2013 - May month in Vilnius. There were asked bank stakeholders.

When asked what position works in Vilnius College of Banking Studies program students were getting the answers are: a personal banker, manager, chief manager, customer service specialist. Bank employees are choosing a graduate of the individual conversation (24 respondents), followed by pointed, Vilnius College (VIKO) recommendations, in accordance with the selection of the test results. One of the unexpected responses to the post left vacant job is affected by, and the candidate's compliance with the requirements of the position. According to survey results graduate, future employee of the bank must have a general capacity that is theoretical knowledge, organizational skills, knowledge of foreign language, have computer literacy. Bank staff said that in practice the theoretical knowledge needed (indicated by 25 respondents, not required - 5 respondents). Working at the bank needed acquire practical knowledge said yes - 14, no - 16 respondents. Extremely important to have the organizational capacity to graduate (as advocated 28, no - 2 respondents) (Figure 1).

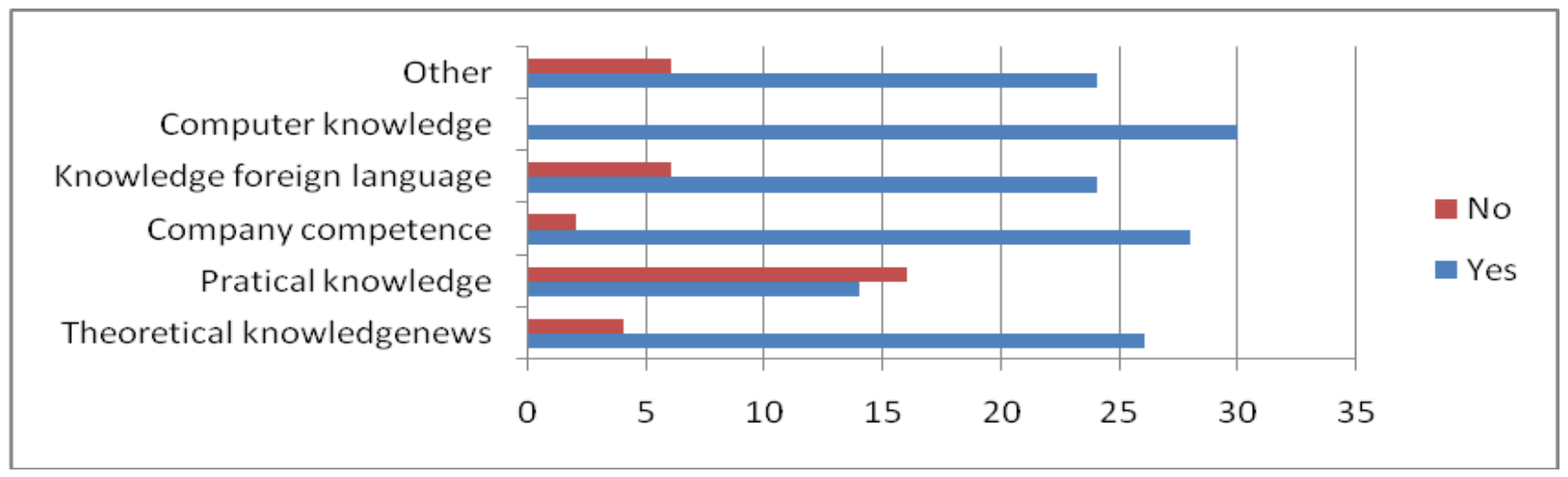

Fig.1. Respondents opinion about requirement elgibility in Vilnius University of Applied Sciences

Source: athors 
Uniquely respondents stated that working at the bank need foreign language and computer literacy. Graduates must demonstrate to the bank and professional aspirations. The question of whether the quality of the students perform the tasks have been answered - 100 per cent, as well. Every bank employee working in a team, so it is very important listening is the ability to work as a team. It is important to assess graduates' response to an exchange situation, the question is whether students are able to respond to the situation said , "yes" - 25, "no" 5. Graduates practice shows your initiative - "yes" - 28, "no" - 2 .

Today's job market requires the development of each employee's work activities. No exceptions and bank employees. Our students have completed their studies college qualifications. According to the respondents graduates continue their studies at universities answered by 20 respondents, the bank organized seminars - 20 respondents, improving their qualifications, others - 14 and even abroad, said 6 respondents. Working in a bank (practical activities) requires that a graduate must have certain professional knowledge, to be able to complete the appropriate documentation to know foreign languages. Respondents were asked to answer to question about personal characteristics. Respondents' opinion is presented in Figure 2.

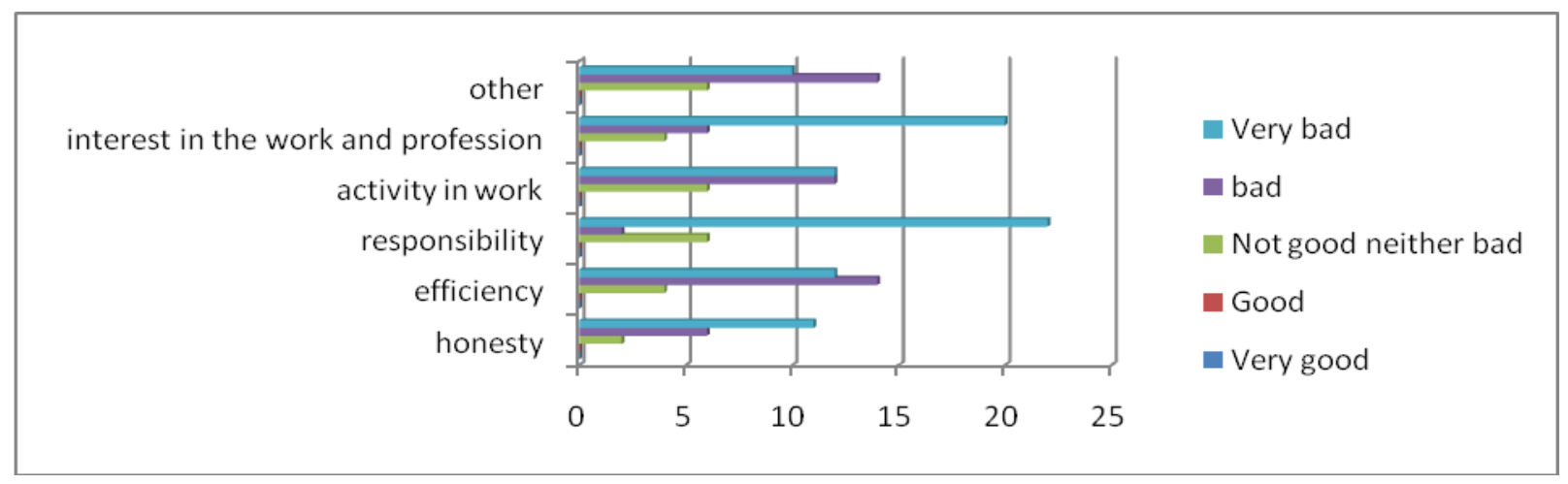

Fig.2. Respondents answer about personal characteristic

Source: athors

Respondents were ask about practical skills. Respondents answer are presented in Figure 3.

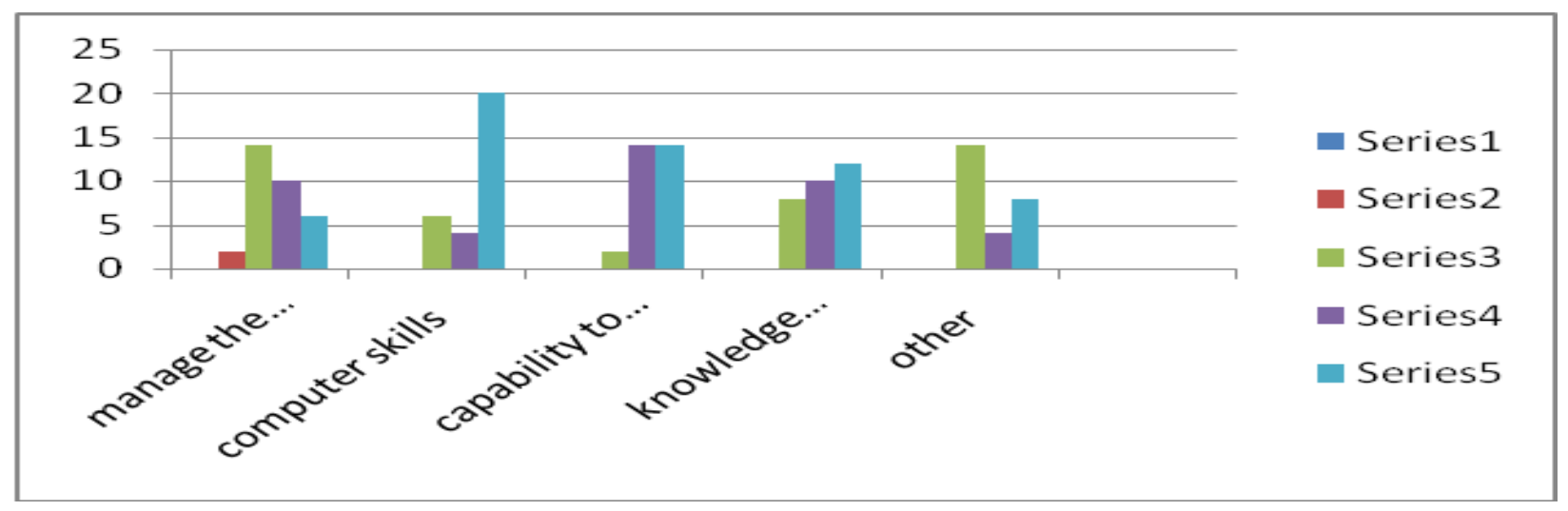

Fig.3. Respondents answer about practical skills

Source: athors

Respondents were asked to evaluate the professional skills of our graduates in a five-point system. Most graduates are able to manage the process, followed by knowledge of foreign languages and computer skills. Gaining Vilnius College general ability of stakeholders to assess very welcome, especially in high- grade (five) all respondents rated their computer literacy: score as well was to evaluate the students, the ability to work in a team, good customer service and the maintenance of an appropriate work rate. The system needed to assess the 
students' personal qualities in practice. In the first row, high- grade graduates Respondents responsibility for a given task, in addition to a high grade was assessed student activity at work. Sadly, our students have lack efficiency and the interest of professional activity.

Respondents were asked about whether graduate banking degree program meets the students in relation to their professional activity requirements. 20 respondents answered "yes", and "no" 8 respondents.

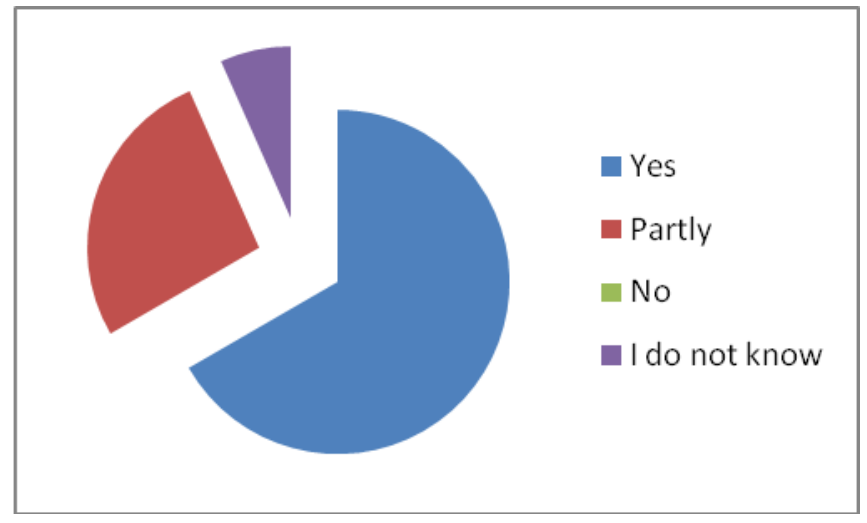

Fig.4. Respondents opinion about banking students'skills eligibility

Source: athors

Alumni qualifications were assessed as follows: "excellent" said ten respondents, "very well" - 12 respondents and "well" - 6 respondents. To answer the last question, all respondents were distributed very unevenly. Most of the respondents would like to cooperate with the administration of the Faculty of Economics VIKO discussing the content of practice, it is said 10 respondents, practice targets - 8 respondents. In determining a student's practical assessments and developing practical tasks responded accordingly after only 2 respondents.

\section{Conclusions}

The components of professional competences are a composite of personal attributes (capacities, motives, personality traits, self -image, aptitudes, attitudes, values, personality, etc.) which complement and integrate themselves in conjunction with other elements that are related to contexts of work (knowledge, abilities, skills, values, behaviors, actions, experience, etc.).

The use of professional competences and their context in jobs refers primarily to the efficiency, effectiveness, and successfulness through collaboration and problem solving in which the task was carried out. It also refers to the capacity to cope with changing professional contexts.

The study involved 30 respondents expressed the view that graduates are opting for practical activities by individual interviews, recommendations and screening test results. All graduates are satisfied. If you desire their qualification at each level. Graduates sufficient theoretical knowledge, organizational skills, are well aware of foreign languages. High rated general graduates basic skills. The study showed that personal characteristics affect employment. Responsibility and activity impact work efficiency. Bank employees are willing to cooperate VIKO Administration Faculty of Economics. The main areas of cooperation are: discussion of the practice content and practice goals.

\section{References}

Adamonienè, R.; Ruibytė L. 2010. Competence of the head of the education system - forming tendencies. Management theory and study for rural business and infrastructure development. No 5 (24). Research papers. ISSN 1822-6760

Balkienè, K. 2013. Sustainable innovativeness: issues and public policy, Journal of Security and Sustainability Issues 3(2): 53-76. DOI: http://dx.doi.org/10.9770/jssi.2013.3.2(5) 
Chomsky, N. 1957. Syntactic Structures. Mouton \& Co. p.117.

David Long, L. 2009. Human Resource Management in the value of a knowledge- based society, Business: Theory and Practice 10(3): 233-246.

Draganidis, F.; Mentzas, G. 2006. Competency based management: A review of systems and approach, Information Management \& Computer Security 14(1): 51-64.

Esteves, M. 2009. Construction and development of the professional competences of teachers, Educational sciences journal 8: 33-44.

Herringer, J. M. 2002. Once isn’t enough when measuring staff competence, Nursing management 33(2): 22.

Išoraitė, M. 2013. Motivation tools though lenses of prospective employees, Entrepreneurship and Sustainability Issues 1(2): 116123. DOI: http://dx.doi.org/10.9770/jesi.2013.1.2(6)

Jakiūnienè, R.; Rekašiūtė, L. 2010. Modern specialist expertise: theory and practice of harmony. International scientific - practical conference. Kaunas: Kaunas College.

Jakubè, A.; Juozaitis, A. 2012. General competencies of higher education. Methodical recommendations. Vilnius: Vilniaus universitetas. ISBN 978-9955-526-89-6

Laužikas, M.; Mokšeckienè. 2013. The role of creativity in sustainable business, Entrepreneurship and Sustainability Issues 1(1): 10-22. DOI: http://dx.doi.org/10.9770/jesi.2013.1(2)

Law on Higher Education and research of the Republic of Lithuania. 2009. Valstybès žinios [Official gazette] No 54-2140.

Le Boterf, G. 1997. De la Compétence à la Navigation Professionnelle. Paris: Les Éditions d'Organisation.

Lithuanian Labour Market Training Authority. 2007. Lithuanian national qualifications frameworks outline.

Liučvaitienè, A.; Paunksnienè, J. 2011. Professional competence transformation in the business environment. Conference proceedings, Lithuanian economy teachers association, 75-81.

Martišauskienė, E. 2009. Teachers' approach to capacity as professional skills strand, Acta paedagogica Vilnensia 22: 88-101. ISSN 1392 $-5016$.

Matei, A.; Savulescu, C. 2012. Towards sustainable economy through information and communication technologies development: case of the EU, Journal of Security and Sustainability Issues 2(2): 5-17. DOI: http://dx.doi.org/10.9770/jssi.2012.2.2(1)

McClelland, D. C. 1973. Testing for competence rather than for 'intelligence', American Psychologist 28: 1-14.

Moore, L. L.; Rudd, R. D. 2004. Leadership sklls and competencies for extension directors and administrators, Journal of Agriculture Education 45(3): 22-33.

Pickett, L. 1998. Competencies and managerial effectiveness: Putting competencies to work, Public Personal Management 27(1): 103115.

Qualifications and Training Foundation. 2012. Vocational standard methodology, p.3.

Raišienè, A.G. 2012. Sustainable development of interorganizational relationships and social innovations, Journal of Security and Sustainability Issues 2(1): 65-76. DOI: http://dx.doi.org/10.9770/jssi/2012.2.1(6)

Raišienè, A.G.; Jonušauskas, S. 2013. Silent issues of ICT era: impact of techno-stress to the work and life balance of employees, Entrepreneurship and Sustainability Issues 1(2):108-115. DOI: http://dx.doi.org/10.9770/jesi.2013.1.2(5)

Rychen, D.D.; Sagalnik, L.H. (Eds.). Defining and selecting key competencies. Göttingen: Hogrefe \& Huber D.S.Rychen, 45-66.

Spencer, L. M.; Spencer, S. M. 1993. Competence at work. Models for superior performance. New York: Willey and Sons.

Taylor, F. 1911. The principles of scientific management. New York: Harper \& Row.

Vasiliūnaite, R. 2014. Sustainable development: methodological approaches toward issues, Journal of Security and Sustainability Issues 3(3): 69-75. DOI: http://dx.doi.org/10.9770/jssi.2014.3.3(6) 
Wahl, M.; Prause, G. 2013. Toward understanding resources, competencies, and capabilities: business model generation approach, Entrepreneurship and Sustainability Issues 1(2): 67-80. DOI: http://dx.doi.org/10.9770/jesi.2013.1.2(1)

Weinert, F. 2001. Concept of competence: a conceptual classification, in defining and Selecting Key Competency and competency, Available on the

Internet: <http://www.deseco.admin.ch/bfs/deseco/en/index/01.parsys.70925.downloadList.59988.DownloadFile.tmp/2001 annualreport.pdf>

Margarita IŠORAITÉ. Doctor of social science in Vilnius Gediminas technical university, name of associated professor was given in Mykolas Romeris University in Lithuania. Associated professor in Vilnius College. Research interests: human resource management, strategic marketing, marketing management, advertisement.

Laimutė STEIBLIENE். Lecture of Vilniaus Kolegija/University of Applies Sciences. Master degree in Finance, Vilnius University. Research interests: human resource management, marketing management, advertisement.

Gitana MEČ́̇̇JENĖ. Lecturer, Head of Banking studies department in Vilniaus Kolegija/University of Applied Sciences. Master degree in Economics, Vilnius University. Research interests: human resource management, study methods, students' competencies.

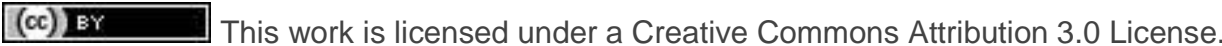

